\title{
Iranian Female Adolescents' Reproductive Health Needs: A Systematic Review
}

\author{
Sepideh Panjalipour ${ }^{1}$, Zahra Bostani Khalesi ${ }^{*} \oplus$, Seyedeh Noshaz Mirhaghjoo ${ }^{1}$
}

\begin{abstract}
Objectives: The aim of the present study was to review female adolescents' reproductive health needs (RHN).

Materials and Methods: We performed this systematic review using the Scopus, PubMed, Google Scholar and Science Direct databases as well as Magiran for English articles written by Iranian authors using the keywords "Female Adolescent", "Reproductive Health", "Reproductive Health Needs" and "Iran".

Results: One hundred forty-eight references were identified. Two reviewers assessed the quality of the included studies. Twentyfive quantitative and qualitative studies met the inclusion criteria. All of the Iranian studies that investigated the RHN of female adolescents were entered the study. In 16 studies, an assessment was conducted using a questionnaire, 9 studies used semi-structured interviews. The results can be divided into 3 general groups of needs, including special educational needs, comprehensive counseling and adolescent-friendly services.

Conclusions: Our findings indicate that most adolescents have an unmet need for reproductive health services and services are not friendly. Therefore, it is suggested that future efforts should be directed toward need-based interventions to improve adolescent reproductive health.
\end{abstract}

Keywords: Adolescence, Reproductive health, Needs assessments, Iran

\section{Introduction}

Adolescence is a transitional stage of psychological and physical development that brings change, growth, and, all too often, health risks to reproduction (1). It is considered by the World Health Organization (WHO) as the period between 10 and 19 years of age (2).

The need for quality improvement in health services intended for adolescents, including health care services related to human reproduction, has been recognized around the world (3). It was reported that sexual violence, pregnancy, sexually transmitted diseases (STDs), abortion, psychological well-being Influence the reproductive health of adolescents (4). About 100 million become infected with a treatable sexually transmitted infection. In addition, about 15 million adolescent girls aged 15 to 19 give birth and 3 million girls aged 15 to 19 undergo unsafe abortions every year (5). Since abortion is illegal in Iran, there is a lack of data demonstrating the prevalence of abortion in adolescents (4). Universally, about $40 \%$ of all new HIV infections occur in young people according to recent estimates (2). However, there is not enough data on HIV due to the lack of reporting from the private sector (4).

Availability of information resources and access to reproductive health services is also essential to facilitate healthy pregnancies and births (6).
A health needs assessment is a systematic process to ensure that all people have access to quality essential health services in an effective, efficient and safe way (2). Respecting the needs and concerns of adolescents is an essential element to create a successful health program (7). Undertaking comprehensive adolescent's reproductive health needs (RHN) assessments combined with self-care is a good method to improve the quality of life in young people (8). However, the existing studies indicate that the aspect of needs in reproductive health care services for adolescents is not well understood (5). In addition, there is a gap between the needs and current program planning for adolescent health in unindustrialized countries (9). Adolescents often lack basic reproductive health information and access to inexpensive, confidential reproductive and sexual health-care services (10). Access to adolescent-friendly services is the key to maintaining a healthy reproductive system (3). Obtaining sexual and reproductive health services is limited by the concerns about the ability to pay and lack of understanding of health care providers (11). The lack of parent-adolescent relationship prevents them from talking about their reproductive health concerns (12).

Despite the availability of existing knowledge about the adolescents' RHN, relevant studies are also scattered across a wide range of journals. On the other hand, there 
is no framework or single definition for adolescents' RHN. Therefore, a systematic review was conducted to examine the adolescents' RHN.

\section{Materials and Methods}

A systematic review was undertaken to review and synthesize studies investigating adolescents' RHN.

Systematic methods of review should build on a detailed and well-described protocol that qualifies the hypothesis, rationale and planned methods. In this study, PRISMA-P (Preferred Reporting Items for Systematic Reviews and Meta-Analyses for Protocols) 2015 checklist was used as criteria for eligibility for the review (13).

\section{Search Strategy}

Systematic searches of 8 electronic databases were conducted. Electronic databases for English articles were the PubMed, Scopus, Science Direct, and Google Scholar and Magiran, IranMedex, IranDoc, SID (Scientific Information Database), and Google Scholar for Persian articles. The search in each database included all published literature by Iranian authors using the keywords "Female Adolescent", "Reproductive Health", "Reproductive Health Needs" and "Iran". References in the included articles were snowballed to ascertain other potentially eligible articles. The gray literature was searched for any non-published relevant articles. In addition to our scientific articles, we included relevant books.

\section{Screening}

All qualitative and quantitative studies were included in this review if they were written in Persian or English language; they focused on reproductive health and its domains; they were original research articles with the qualitative or quantitative approach; they provided suitable and adequate information about reproductive health; they were published in a peer-reviewed local or foreign journal; they had focused on Iranian adolescents and were published between June 2007 and July 2017. Studies were excluded from this review if the study participants were not adolescents and if they did not report the specific results of female adolescents.

All studies that were eligible for inclusion were screened by 2 reviewers using checklists. SIGN (Scottish Intercollegiate Guidelines Network) checklist was used for quantitative study whereas the CASP (Critical Appraisal Skills Program) tool was developed for qualitative study. SIGN checklist was used for descriptive/cross-sectional studies (14) as well as the CASP (15) quality assessment scale for qualitative studies (Table 1).

Data were extracted and organized under the following headings: author and year to establish a historical timeline, study purpose and design, sample size, data collection methods, main findings of the study and limitations. If a decision could not be made, a third reviewer was consulted.
Table 1. Included Studies and Appraisal Checklists

\begin{tabular}{ll}
\hline Study Design & Appraisal Checklists \\
\hline Cross-sectional study $(n=3)$ & SIGN \\
Qualitative study $(n=13)$ & CASP \\
\hline
\end{tabular}

Abbreviations: SIGN, Scottish Intercollegiate Guidelines Network; CASP, Critical Appraisal Skills Program.

\section{Results}

Twenty-five papers were included in the review from an initial search of more than 148 records (Figure 1).

\section{Study Characteristics}

The majority $(n=16)$ of studies were conducted using a quantitative method of cross-sectional studies and the remaining 9 studies had a qualitative method. Questionnaires were used to collect data in all quantitative research study. But data collection method in qualitative studies was in-depth semi-structured interviews and focus groups (Table 2).

\section{RHN of Female Adolescents}

The final synthesis was conducted on 25 articles with eligibility criteria. The results obtained from relevant articles can be divided and reviewed in 3 general groups of needs, including special educational needs, comprehensive counseling and adolescent-friendly services.

The most important educational needs of adolescents include STD/HIV, reproductive anatomy and physiology, puberty and menstrual health common cancers among women and contraception.

Comprehensive counseling includes family planning issues sexual and reproductive health services for adolescents, counseling about teen pregnancy, violent behavior, gender relations, sexual responsibility, sexually transmitted infection, and sexual assault prevention. Comprehensive counseling has the following characteristics: it reaches $100 \%$ of adolescents, involves all adolescents, parents, counselors, and community partners, developmental and sequential, unique and responsive services, focuses on needs and goals, and measures program effectiveness.

The WHO identified 5 key characteristics of adolescentfriendly services as follows: equitable, accessible, acceptable, appropriate and effective. In addition, the characteristics of adolescent-friendly services include the characteristics of providers (Familiarity with adolescent physiology and development, working with and serving youth training, effective interpersonal skills, sexual health assessment taken or updated at every visit, etc), the health facility (convenient location, adequate space, comfortable surroundings, etc), and the health facility programming (flexible hours, offering lunch, evening and weekend appointments, boys and young men were welcomed and served, drop-in clients were welcomed and appointments were arranged rapidly, etc). 


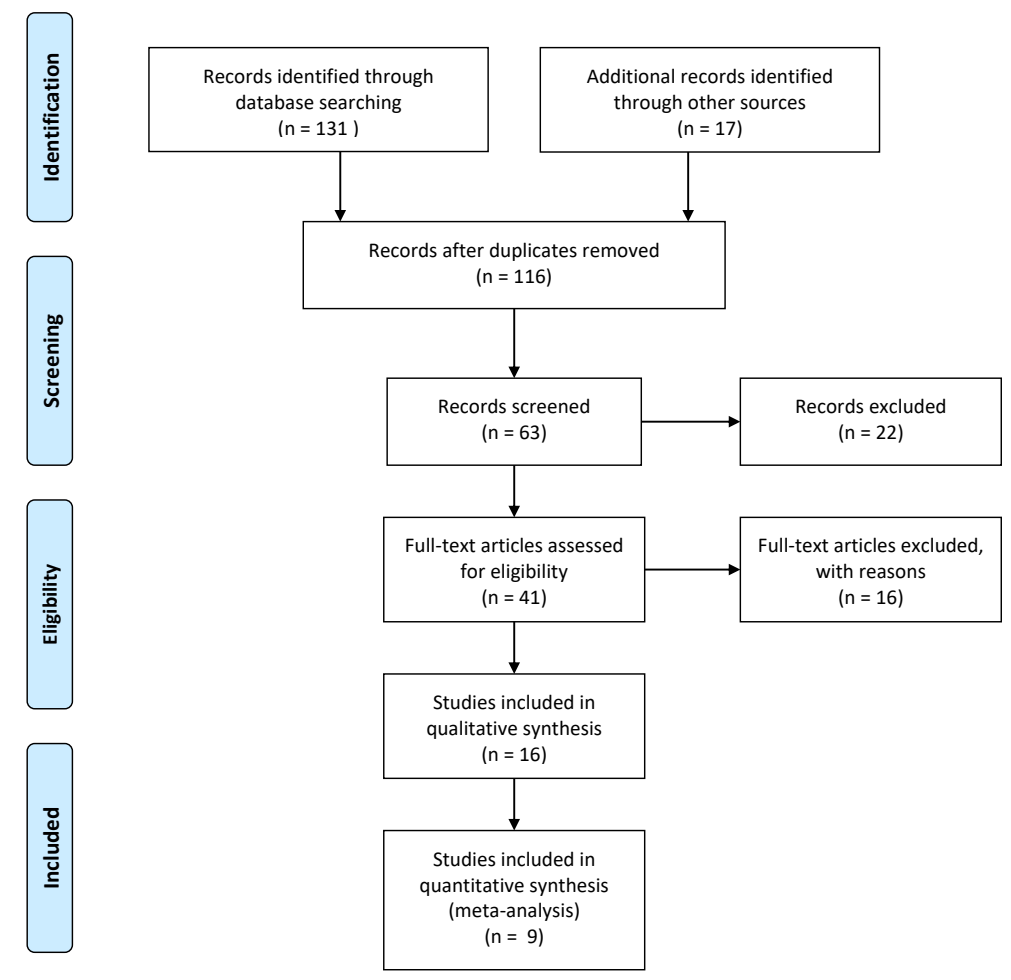

Figure 1. PRISMA Flow Diagram.

\section{Discussion}

This paper drew on a variety of sources in the research literature and introduced strong evidence of female RHN. The potential benefits of this report are described as evidence-based RHN (3). Since our study was a systematic search of the literature, we feel that the results are an exact representation of female RHN.

Articles frequently showed a wide range of female RHN. The results of various studies have revealed the necessity of training in various areas of reproductive health for female adolescence. Masoumi et al performed a study on female high school students in Hamadan and reported the necessity of reproductive health education (39). The necessity for reproductive health education could be because of the lack of sufficient resource and information for female adolescents and healthcare providers. There is a need for broadcast dissemination of reproductive health information and recommendations to all levels of health care so as to ensure that females are alert of, and comprehend, the recommendations notifying reproductive health (6).

The results showed that most of females had weak knowledge about reproductive physiology, menstrual health, and STD/HIV. In this regard, the results of this review concur with some foreign articles $(5,6)$.

Among reviewed studies, some studies have reported that there are barriers to accessing the available reproductive health services. Shariati et al conducted a qualitative study on adolescent girls and reported barriers to accessing reproductive health services. The main barriers were socio-cultural barriers, political barriers, constructional and executive barriers (32). One of the barriers identified by these youths was limited referral services (19). These results were confirmed by those of the previous studies conducted on the issue.

The results of the previous studies demonstrated that one of the most important needs for reproductive health education is teaching life skills. Skills-based health education including life skills is an important component of reproductive health services $(3,7)$.

Among the reviewed studies, only one study had considered adolescent-friendly services. Shariati et al reported the characteristics of adolescent-friendly reproductive health services for female adolescents (38). It showed that adolescent-friendly services have not yet been adequately addressed in Iran. However, access to adolescent-friendly health services is vital for ensuring the well-being of adolescents and their reproductive health. Due to the lack of adolescent-friendly services in the Iranian health care program, the reproductive health programs may be faced with more difficulties in the subsequent decades.

Consistent with the results of foreign studies, this review showed the necessity for support of healthcare providers. The findings of a study by Shahhoseini show a need for participation, support, and leadership of health care providers in formulation and implementation of policies related to adolescents' reproductive health (34).

Regarding another aspect of RHN, this review showed that there is not enough time to address counseling. 
Table 1. Characteristics and Main Findings Included in the Systematic Review

\begin{tabular}{|c|c|c|c|c|}
\hline Author (Year) & Study Design & Study Participants & $\begin{array}{l}\text { Data Collection } \\
\text { Methods }\end{array}$ & Summary of Findings \\
\hline Dolatian et al $(2007)^{16}$ & $\begin{array}{l}\text { Descriptive } \\
\text { study }\end{array}$ & $\begin{array}{l}1100 \text { female } \\
\text { students }\end{array}$ & Questionnaire & $\begin{array}{l}\text { Student knowledge was generally at a moderate level and they had a positive attitude toward the Thames. Their knowledge } \\
\text { concerning premarital genetic counseling was more and about sexual health was less }\end{array}$ \\
\hline Olfati and Aligholi (2008) ${ }^{17}$ & $\begin{array}{l}\text { Cross- } \\
\text { sectional }\end{array}$ & 300 teenage girls & WHO's questionnaire & The level of knowledge regarding reproductive health issues among adolescent girls was quite weak \\
\hline Garmaroudi et al $(2010)^{18}$ & $\begin{array}{l}\text { Cross- } \\
\text { sectional }\end{array}$ & $\begin{array}{l}2400 \text { high school } \\
\text { students }\end{array}$ & Questionnaire & The frequency of risky behaviors among the participants was high \\
\hline Jalali Ariaet al $(2010)^{19}$ & $\begin{array}{l}\text { Descriptive } \\
\text { study }\end{array}$ & $\begin{array}{l}400 \text { parents and } 50 \\
\text { teachers from girls' } \\
\text { high school }\end{array}$ & Questionnaire & The majority of teachers and parents agree with reproductive health education in premarrige classes and high school \\
\hline Ramezanzadeh et al $(2010)^{20}$ & $\begin{array}{l}\text { Descriptive- } \\
\text { analytical }\end{array}$ & $\begin{array}{l}530 \text { health care } \\
\text { providers }\end{array}$ & Questionnaire & Comprehensive reproductive health package is necessary for all the health centers \\
\hline Golchin et al $(2012)^{21}$ & $\begin{array}{l}\text { Qualitative } \\
\text { study }\end{array}$ & $\begin{array}{l}38 \text { girls of } 12- \\
20 \text { years old }\end{array}$ & $\begin{array}{l}\text { Semi-structured } \\
\text { interviews }\end{array}$ & Puberty was an unpleasant experience for the majority of girls. \\
\hline Farahani et al $(2012)^{22}$ & Survey & $\begin{array}{l}1743 \text { female } \\
\text { adolescents }\end{array}$ & Questionnaire & $\begin{array}{l}\text { In Iran, female adolescents are susceptible to sexual and reproductive health hazards due to lack of adequate knowledge about } \\
\text { sexual health and condom use. }\end{array}$ \\
\hline Shahhosseini et a I(2012) $)^{23}$ & $\begin{array}{l}\text { Qualitative } \\
\text { study }\end{array}$ & $\begin{array}{l}67 \text { female } \\
\text { adolescents } \\
\text { between 12-18 } \\
\text { years }\end{array}$ & $\begin{array}{l}\text { Focus group } \\
\text { discussions }\end{array}$ & $\begin{array}{l}\text { The adolescents' RHN emphasized on general services, exclusive services, reinforcement of facilitators, reduce barriers and } \\
\text { appropriate management of services. }\end{array}$ \\
\hline Javadnoori et al $(2012)^{24}$ & $\begin{array}{l}\text { Qualitative } \\
\text { study }\end{array}$ & $\begin{array}{l}\text { Female } \\
\text { adolescents aged } \\
14-18\end{array}$ & $\begin{array}{l}\text { Individual in-depth } \\
\text { interviews }\end{array}$ & Participants showed great capability to estimate health services delivered for them. \\
\hline Bazarganipour $(2013)^{25}$ & $\begin{array}{l}\text { Descriptive- } \\
\text { analytical }\end{array}$ & 400 girl students & Questionnaire & The majority of girl students have moderate knowledge about reproductive health issues. \\
\hline Shahhosseini et al $(2013)^{26}$ & $\begin{array}{l}\text { Cross- } \\
\text { sectional }\end{array}$ & 2010 girl students & $\begin{array}{l}\text { Self- administered } \\
\text { questionnaire }\end{array}$ & $\begin{array}{l}\text { Attention to adolescents' emotional health the is emphasized, otherwise irrecoverable serious problems may occur in the next } \\
\text { generation's health. }\end{array}$ \\
\hline Roudsari et al $(2013)^{27}$ & $\begin{array}{l}\text { Qualitative } \\
\text { study }\end{array}$ & $\begin{array}{l}\text { Female } \\
\text { adolescents aged } \\
14-18\end{array}$ & $\begin{array}{l}\text { Individual in-depth } \\
\text { interviews }\end{array}$ & $\begin{array}{l}\text { Despite existence of socio-cultural doubtful regarding adolescent's sexual health education, these problems are manageable to } \\
\text { some extent. }\end{array}$ \\
\hline Abedian et al $(2013)^{28}$ & $\begin{array}{l}\text { Descriptive- } \\
\text { analytical }\end{array}$ & $\begin{array}{l}548 \text { female } \\
\text { students }\end{array}$ & Questionnaire & $\begin{array}{l}\text { The maximum score of barriers and facilitators to sexual and reproductive health services was related to "Fear of stigmatization" } \\
\text { and "Young people's participation in sexual and reproductive health services provision", respectively. }\end{array}$ \\
\hline
\end{tabular}




\begin{tabular}{|c|c|c|c|c|}
\hline Author (Year) & Study Design & Study Participants & $\begin{array}{l}\text { Data Collection } \\
\text { Methods }\end{array}$ & Summary of Findings \\
\hline Mosavi et al $(2014)^{29}$ & $\begin{array}{l}\text { Qualitative } \\
\text { study }\end{array}$ & Adolescent girls & $\begin{array}{l}\text { Semi-structured } \\
\text { interviews }\end{array}$ & The necessity of providing SRH services for female adolescent confirmed by most participants \\
\hline Shahhosseiniet al (2014) $)^{30}$ & $\begin{array}{l}\text { Cross- } \\
\text { sectional }\end{array}$ & $\begin{array}{l}548 \text { female } \\
\text { students }\end{array}$ & Questionnaire & $\begin{array}{l}\text { The results from this study indicate Programming is necessary for female students to the health promotion and development of } \\
\text { adolescent. }\end{array}$ \\
\hline $\begin{array}{l}\text { Mohammad-Alizadeh et al } \\
(2014)^{31}\end{array}$ & $\begin{array}{l}\text { Cross- } \\
\text { sectional }\end{array}$ & $\begin{array}{l}1017 \text { female } \\
\text { students }\end{array}$ & Questionnaire & Menstrual hygiene and puberty education is necessary for girls to enable them to have a healthy reproductive life in future \\
\hline Shariati et al $(2014)^{32}$ & $\begin{array}{l}\text { Qualitative } \\
\text { study }\end{array}$ & $\begin{array}{l}247 \text { adolescent } \\
\text { girls }\end{array}$ & $\begin{array}{l}\text { Focus groups } \\
\text { discussion and semi- } \\
\text { structured interview }\end{array}$ & The results from this study support three main barriers: political structural, cultural barriers. \\
\hline Yari et al $(2015)^{33}$ & $\begin{array}{l}\text { Qualitative } \\
\text { study }\end{array}$ & $\begin{array}{l}25 \text { female students } \\
\text { and } 10 \text { key } \\
\text { members }\end{array}$ & $\begin{array}{l}\text { Focus groups } \\
\text { discussion and semi- } \\
\text { structured interview }\end{array}$ & Most key informants stressed that reproductive health services is necessary for female adolescents \\
\hline Shahhosseini et al $(2015)^{34}$ & $\begin{array}{l}\text { Cross- } \\
\text { sectional }\end{array}$ & $\begin{array}{l}72 \text { health care } \\
\text { providers }\end{array}$ & Questionnaire & $\begin{array}{l}\text { The results from this study show support, guidance, and participation of health care providers is necessary in formulation and } \\
\text { performance of adolescents' reproductive health policies. }\end{array}$ \\
\hline Hosseininasab et al $(2015)^{35}$ & $\begin{array}{l}\text { Qualitative } \\
\text { study }\end{array}$ & $\begin{array}{l}40 \text { teenage }(13- \\
19 \text {-year-old) girls }\end{array}$ & $\begin{array}{l}\text { Individual in-depth } \\
\text { interviews }\end{array}$ & Adolescents girls need a comprehensive counseling program to improve their reproductive health status \\
\hline Mohammadi et al (2016) 36 & $\begin{array}{l}\text { Qualitative } \\
\text { study }\end{array}$ & $\begin{array}{l}16 \text { female, } 5 \\
\text { midwives, and } 2 \\
\text { physicians }\end{array}$ & $\begin{array}{l}\text { Semi-structured } \\
\text { interview }\end{array}$ & $\begin{array}{l}\text { Stigma in sexual and reproductive issues cause limitations on female for using reproductive health services. Thus, strategies are } \\
\text { demanded for overcoming this stigma. }\end{array}$ \\
\hline Motlagh et al $(2016)^{37}$ & Descriptive & 2842 adolescent & Questionnaire & The most important need for health education in all centers is teaching life skills \\
\hline Shariati et al (2016) 38 & $\begin{array}{l}\text { Qualitative } \\
\text { study }\end{array}$ & $\begin{array}{l}247 \text { adolescent } \\
\text { girls }\end{array}$ & $\begin{array}{l}\text { Focus groups } \\
\text { discussion and semi- } \\
\text { structured interview }\end{array}$ & $\begin{array}{l}\text { The characteristics of adolescent-friendly reproductive health services were classified in four categories: personnel factors, physical } \\
\text { and environmental factors of the services providers, management factors and stimulus factors. }\end{array}$ \\
\hline Masoumi et al $(2017)^{39}$ & $\begin{array}{l}\text { Cross- } \\
\text { sectional }\end{array}$ & 346 students & WHO's questionnaire & The study results revealed the necessity of training in various areas of reproductive health in female high school students. \\
\hline Abdollahi et al $(2017)^{40}$ & $\begin{array}{l}\text { Descriptive } \\
\text { study }\end{array}$ & $\begin{array}{l}655 \text { high school } \\
\text { girls }\end{array}$ & WHO's questionnaire & Most adolescent's knowledge about reproductive health was weak and solving any barrier on this should be addressed \\
\hline
\end{tabular}


Finding of the study by Bostani et al shows that there is little time to spend counseling with clients (10). The current minimal availability of reproductive health counseling service suggests that adolescents' needs are not being fully met. However, counseling is needed to decrease the level of reproductive problems. This demonstrates the need for going beyond training health providers in counseling and integrating demand and promotion strategies. The handbook of counseling should be designed to prepare all levels of health providers to use communication and counseling skills to assess and address clients' comprehensive RHN.

\section{Limitations}

The main limitation of this review was excluding articles that were not available via the Internet. Although, articles are there to assess female reproductive needs, they need to be readily available to those who need them. However, in attempting to obtain all documents that fitted the inclusion criteria, several studies may have been lost because they did not match the search keyword used.

\section{Conclusions}

This review presents a comprehensive summary of female RHN. RHN assessment provides an avenue for health providers and decision maker to access need-based interventions for female adolescent health care. In this study, 25 documents were found from the international literature that satisfied the inclusion criteria and addressed female RHN. In spite of the quality of the articles and the similarity of the needs, one article recommended adolescent-friendly health care services. In this part of the study, we suggest several recommendations for future investigation into reproductive health intervention and promotion efforts. Need-based intervention is an effective strategy for improving the reproductive health status of adolescents. Therefore, carefully controlled intervention studies are necessary to survey and comprehend the effects of need-based intervention. Evidence-based intervention studies are also needed to evaluate the impact of different promotion strategies on adolescent reproductive health outcomes.

\section{Conflict of Interests}

Authors declare that they have no conflict of interests.

\section{Ethical Issues}

Not applicable.

\section{Financial Support}

None.

\section{References}

1. United Nation Population Fund (UNFPA) Adolescent reproductive health. New York: UNFPA; 2016. Available from: http://www.unfpa.org/resources/issue-3-adolescent- reproductive-health.

2. World Health Organization. Health for the world's adolescents: A second chance in the second decade. 2015. http://public.tableausoftware.com/profile/digitalteam\#!/ vizhome/shared/3JW3RBSZ3. Published 2015.

3. United Nations. We can end poverty: Millennium development goals and beyond. http://www.un.org/ millenniumgoals/childhealth.shtml. Published 2015.

4. Vakilian K, Mirzaii K. Reproductive health in international conference on population and development goals. Oman Med J. 2011;26(2):143-147. doi:10.5001/omj.2011.36

5. Nove A, Matthews Z, Neal S, Camacho AV. Maternal mortality in adolescents compared with women of other ages: evidence from 144 countries. Lancet Glob Health. 2014;2(3):e155-164. doi:10.1016/s2214-109x(13)70179-7

6. Khalesi ZB, Simbar M, Azin SA. A qualitative study of sexual health education among Iranian engaged couples. Afr Health Sci. 2017;17(2):382-390. doi:10.4314/ahs. v17i2.12

7. Bostani Khalesi Z, Simbar M, Azin SA, Zayeri F. Public sexual health promotion interventions and strategies: A qualitative study. Electron Physician. 2016;8(6):2489-2496. doi:10.19082/2489

8. Karamouzian M, Shokoohi M. Sexual and reproductive health education in Iranian schools. J Adolesc Health. 2014;55(1):149-150. doi:10.1016/j.jadohealth.2014.04.009

9. Bokaie M, Khalesi ZB, Yasini-Ardekani SM. Diagnosis and treatment of unconsummated marriage in an Iranian couple. Afr Health Sci. 2017;17(3):632-636. doi:10.4314/ ahs.v17i3.5

10. Bostani Khalesi Z, Ghanbary Khanghah A. Perception and experience of married women of reproductive age about the importance of sexual health education: A content analysis study. Iranian Journal of Obstetrics, Gynecology and Infertility. 2015;18(172):7-17.

11. Djalalinia S, Ramezani Tehrani F, Malekafzali H, Hashemi Z, Peykari N. A youth-led reproductive health program in a university setting. Med J Islam Repub Iran. 2015;29:210.

12. Taghizadeh Maghaddam H, Bahreini A, Ajilian Abbasi M, Fazli F, Saeidi M. Adolescence Health: the Needs, Problems and Attention. Int J Pediatr. 2016;4(2):1423-1433. doi:10.22038/ijp.2016.6569

13. Afrand M, Ling CP, Khosrotehrani S, Flores-Mir C, Lagravere-Vich MO. Anterior cranial-base timerelated changes: A systematic review. Am J Orthod Dentofacial Orthop. 2014;146(1):21-32.e26. doi:10.1016/j. ajodo.2014.03.019

14. Malpass A, Shaw A, Sharp D, et al. "Medication career" or "moral career"? The two sides of managing antidepressants: a meta-ethnography of patients' experience of antidepressants. Soc Sci Med. 2009;68(1):154-168. doi:10.1016/j.socscimed.2008.09.068

15. Guyatt GH, Sackett DL, Cook DJ. Users' guides to the medical literature. II. How to use an article about therapy or prevention. A. Are the results of the study valid? Evidence-Based Medicine Working Group. JAMA. 1993;270(21):2598-2601.

16. Dolatian M, Hajian S, Simbar M, Alavi-Majd $H$. Knowledge and attitude of nonmedical students regarding reproductive health. Adv Nurs Midwifery. 2007;17(56):112. doi:10.22037/anm.v17i56.688

17. Olfati F, Aligholi S. A study on educational needs of teenager girls regarding the reproductive health and determination 
of proper strategies in achieving the target goals in Qazvin. J Qazvin Univ Med Sci. 2008;12(2):76-82.

18. Garmaroudi G, Makarem J, Alavi S, Abbasi Z. Health related risk behaviors among high school students in Tehran, Iran. Payesh. 2010;9(1):13-19.

19. Jalali Aria K, Nahidi F, Amir Ali Akbari S, Alavi-Majd H. Parents and teachers' view on appropriate time and method for female reproductive health education. J Gorgan Univ Med Sci. 2010;12(3):84-90.

20. Ramezanzadeh F, Haghollahi F, Shariat $M$, et al. Reproductive health service centers for youth in Iran. Journal of School of Public Health and Institute of Public Health Research. 2010;7(4):1-10.

21. Golchin NA, Hamzehgardeshi Z, Fakhri M, Hamzehgardeshi L. The experience of puberty in Iranian adolescent girls: a qualitative content analysis. BMC Public Health. 2012;12:698. doi:10.1186/1471-2458-12-698

22. Farahani FK, Shah I, Cleland J, Mohammadi MR. Adolescent males and young females in tehran: differing perspectives, behaviors and needs for reproductive health and implications for gender sensitive interventions. J Reprod Infertil. 2012;13(2):101-110.

23. Shahhosseini Z, Simbar M, Ramezankhani A. Female adolescents' reproductive health needs: A qualitative study. Payesh. 2012;11(6):815-823.

24. Javadnoori M, Roudsari RL, Hasanpour M, Hazavehei SM, Taghipour A. Female adolescents' experiences and perceptions regarding sexual health education in Iranian schools: A qualitative content analysis. Iran J Nurs Midwifery Res. 2012;17(7):539-546.

25. Bazarganipour F, Foroozanfard F, Taghavi SA, Hekmatzadeh F, Sarviye M, Hosseini N. Evaluation of Female Youth Educational Needs about Reproductive Health in NonMedical Students in the City of Qom. J Family Reprod Health. 2013;7(2):67-72.

26. Shahhosseini Z, Simbar M, Ramezankhani A, Alavi Majd $\mathrm{H}$, Moslemizadeh N. The challenges of female adolescents' health needs. Community Ment Health J. 2013;49(6):774780. doi:10.1007/s10597-013-9606-6

27. Latifnejad Roudsari R, Javadnoori M, Hasanpour M, Hazavehei SM, Taghipour A. Socio-cultural challenges to sexual health education for female adolescents in Iran. Iran J Reprod Med. 2013;11(2):101-110.

28. Abedian K, Shahhosseini Z. University students' point of views to facilitators and barriers to sexual and reproductive health services. Int J Adolesc Med Health. 2014;26(3):387392. doi:10.1515/ijamh-2013-0316

29. Mosavi SA, Babazadeh R, Najmabadi KM, Shariati M. Assessing Iranian adolescent girls' needs for sexual and reproductive health information. J Adolesc Health.
2014;55(1):107-113. doi:10.1016/j.jadohealth.2013.11.029

30. Shahhosseini Z, Abedian K. Iranian university students' perceived reproductive health needs. Int J Adolesc Med Health. 2014;26(3):339-344. doi:10.1515/ijamh-2013-0308

31. Mohammad-Alizadeh-Charandabi S, Mirghafourvand M, Saghi S, Seidi S, Rahmani A, Zareie S. Practice of Iranian Adolescent Girls Regarding Puberty and Menstrual Hygiene and its Predictors, 2013. Int J Womens Health Reprod Sci. 2014;2(3):195-204. doi:10.15296/ijwhr.2014.28

32. Shariati M, Babazadeh R, Mousavi SA, Najmabadi KM. Iranian adolescent girls' barriers in accessing sexual and reproductive health information and services: a qualitative study. J Fam Plann Reprod Health Care. 2014;40(4):270275. doi:10.1136/jfprhc-2013-100856

33. Yari F, Moghadam ZB, Parvizi S, Nayeri ND, Rezaei E. Sexual and reproductive health problems of female university students in Iran: a qualitative study. Glob J Health Sci. 2015;7(4):278-285. doi:10.5539/gjhs.v7n4p278

34. Shahhosseini Z, Abedian K. Female Adolescents' Reproductive Health Education Needs: Perspectives' of Health Care Providers. Eur Psychiatry. 2015;30 Suppl 1:579. doi:10.1016/S0924-9338(15)30460-0

35. Hosseininasab A, Alidoosti K, Forouhari S. Health-Related Counseling Needs in Adolescent Girls: A Qualitative Study. Health Scope. 2016;5(2):e24601. doi:10.17795/ jhealthscope-24601

36. Mohammadi F, Kohan S, Mostafavi F, Gholami A. The Stigma of Reproductive Health Services Utilization by Unmarried Women. Iran Red Crescent Med J. 2016;18(3):e24231. doi:10.5812/ircmj.24231

37. Motlagh ME, Rejaei L, Jonidi-Jafari A, et al. Priorities in Health Education Needs of Youth Based on Needs Assessment and Stakeholder Involvement, in Areas Covered by the Health Departments of Iran University of Medical Sciences. Journal of Education and Community Health. 2016;3(1):51-57. doi:10.21859/jech-03017

38. Shariati $M$, babazadeh R, Mirzaii Najmabadi K, Mousavi SA. Interpretation of the characteristics of Youth friendly reproductive health services in Iran: A qualitative study. Prev Care Nurs Midwifery J. 2016;6(3):34-47.

39. Masoumi SZ, Kazemi F, Delforouz F, Kousha M, Faradmal J. Educational needs of female adolescents regarding reproductive health: A case study in Hamadan-Iran. Journal of Research and Health. 2017;7(4):927-934. doi:10.18869/ acadpub.jrh.7.4.927

40. Abdollahi F, Geran Ouremi T, Barzegar A, Yazdani Charati J. Knowledge of Girls on Reproductive Health and their Desire for Communication with Mothers about this. J Mazandaran Univ Med Sci. 2017;26(144):28-38.

(c) 2018 The Author (s); This is an open-access article distributed under the terms of the Creative Commons Attribution License (http://creativecommons.org/licenses/by/4.0), which permits unrestricted use, distribution, and reproduction in any medium, provided the original work is properly cited. 